\title{
Contrastive analysis and translation study from a corpus linguistics perspective
}

\author{
Ma ÁNGELES GÓMEZ-CASTEJÓN \\ Catholic University of Leuven
}

Received: 25 August 2011 / Accepted: 16 April 2012

\begin{abstract}
Previous contrastive studies between the English gerund and its Spanish counterparts present serious limitations in the analysis of these constructions. The main objection is the absence of a cognitive approach. In addition, the traditional characterization of the English gerund seems to be inappropriate to determine its nature. We propose that in order to carry out a contrastive analysis of these constructions, it is absolutely necessary to include a cognitive approach. This approach establishes a valid characterization of the English gerund as well as the relationship between this category and its Spanish counterparts. We also include a translation study. The translation study is not limited to the establishment of equivalence relations between the source and target languages, but it also provides translations techniques observed in the translation product. On the whole, parallel corpora and translated texts prove to be extremely useful for both our contrastive analysis and translation study.
\end{abstract}

\section{KEYWORDS:}

Contrastive studies; English gerund; Spanish counterparts; contrastive analysis; cognitive characterization; translation study; parallel corpus

\section{RESUMEN}

Los estudios contrastivos anteriores entre el gerundio inglés y sus equivalentes españoles presentan serias limitaciones en el análisis de estas construcciones. La mayor objeción es la ausencia de un enfoque cognitivo. Además la caracterización tradicional del gerundio inglés resulta inapropiada para determinar su naturaleza. Proponemos que al llevar a cabo un estudio contrastivo de estas construcciones, es absolutamente necesario incluir un enfoque cognitivo. Este enfoque establece una caracterización válida del gerundio inglés así como la relación entre esta categoría y sus contrapartidas españolas. Además incluimos un estudio de traducción. El estudio de traducción no se limita a establecer las relaciones de equivalencia entre la lengua origen y la lengua meta sino que además nos proporciona las técnicas de traducción que se observan en la traducción. En su conjunto, los corpus paralelos y los textos traducidos han resultado extremadamente útiles tanto para nuestro análisis contrastivo como para nuestro estudio de traducción.

\section{PALABRAS CLAVE:}

Estudios contrastivos; gerundio inglés; contrapartidas españolas; estudio contrastivo; caracterización cognitiva; estudio de traducción; corpus paralelo

*Address for correspondence: $\mathrm{M}^{\mathrm{a}}$ Ángeles Gómez-Castejón. Catholic University of Leuven, Square Marguerite 10, C-2, 10000, Bruxelles, Belgique. Tel: 0032 22310473; E-mail: angeles.gomezcastejon@hotmail.com 


\section{INTRODUCTION}

In general, previous contrastive studies between the English gerund and its Spanish counterparts present serious limitations. We have found three specific problem areas in our corpus-based contrastive study between the English gerund and its Spanish counterparts. Firstly, previous contrastive studies display serious limitations in their analysis of these constructions because they consist of a purely functional approach. Secondly, the English gerund has been analysed using different terminology and criteria. Besides, the traditional characterization of the English gerund is not valid because it does not explain all the contexts in which it appears in a consistent way. Finally, the use of corpora and translated texts has aroused controversy and scholars have not reached agreement on the issue.

In the first place, most of the previous studies have simply provided a functional characterization and we argue that it is absolutely necessary to include a cognitive approach in the characterization of the English gerund and its counterparts ${ }^{1}$. This cognitive characterization will help us establish the equivalence between the English gerund and its counterparts in terms of their cognitive resemblance.

Secondly, terminology and criteria have not been homogenous when analysing the English gerund. As regards the terminology, the English gerund has been referred to as gerund, participle and gerund-participle (Quirk, 1985; Huddleston \& Pullum, 2002 respectively). In relation to the criteria, the so-called half-gerunds (Duffley, 2006 and others) represent one of the most prominent examples in this regard. Kortmann (1995: 196) exemplifies these specific cases that have been classified either as gerunds (Ihms, 1981) or participles (Quirk et al. 1985; Pullum, 1991; Kortmann, 1995; Declerck, 1982):

1a. Women having to vote reduces man's political power. (Kortmann, 1995: 196)

1b. Our children hate John singing folk songs. (Kortmann, 1995: 196)

All previous examples have the presence of an inflected noun preceding the -ing (NP + -ing form) in common and these examples highlight that there is some formal confusion between gerund and participle categories. In these cases, the "NP + -ing form" can be interpreted as one single constituent recalling a single event and the -ing form functions as a gerund (e.g. Our children hate John singing folk songs). The treatment of "NP + -ing form" as two different constituents implies that the -ing form functions as a participle (e.g. Our children hate John singing folk songs). From our point of view, this difficulty is the consequence of not adopting a non-discrete approach that includes all the contexts where an ambivalent interpretation may exist.

In order to complete the main difficulties in the analysis of the English gerund, we will analyse its traditional characterization. The English gerund has traditionally been characterized in terms of tense and aspect criteria (i.e. simultaneity/imperfectivity respectively). However, we argue that this description is inadequate, because the English 
gerund can express all temporal and aspectual possibilities. In other words, the English gerund can express simultaneity, anteriority and posteriority, and even no temporal relation at all, as in (2a), (2b), (2c) and (2d) respectively, as well as imperfective and perfective readings, as in (2e):

2a. [...] she liked telling him about how much she had liked it no less than he liked hearing about it. (SAB 108)

2b. She remembered sniffing at Jolyon's little head with such pleasure. (SWEE 896)

2c. He dusted the elbows of his jacket as he rose, asking whether she would mind dropping him at a store nearby, (NONE 635)

2d. Does an artist's life entail sleeping with anyone and everyone? (YOU 30)

2e. Just thinking about those years, Thelma having an affair with Harry almost right up to when she died, (RAB 195)

Also, there has been some controversy in the literature over the issue of the adoption of a bilingual parallel corpus and translated language. As far as corpus use is concerned, during the fifties and sixties it was questioned and its development slowed down due to the impact of the principles of Chomsky's generative grammar. The purpose of study of generative grammar was based on competence or the listener/speaker's innate knowledge of his/her language and hence it follows that the researcher's intuition was the methodology to apply. In addition, from the generative perspective the corpus language provided data which were a kind of reflection on the language interpreted as a universal phenomenon. Despite the preponderance/predominance of Generativism, Corpus linguistics kept “moving” in order to find answers to the inconsistencies of generative grammar in the description of language, as Teubert (2004: 107) points out: "Corpus linguistics is a fairly new approach to language. It emerged in the 1960s, at the same time as Noam Chomsky made his impact on modern language studies. His Syntactic Structures appeared in 1957, [...] Yet while language theory became increasingly interested in language as a universal phenomenon, other linguistics had become more and more dissatisfied with the descriptions they found for the various languages they dealt with. [...] Certain features of the language were insufficiently described”.

In the early eighties the corpus experienced a tremendous growth as a source of data for empirical studies of language and consequently the focus of linguistics shifted from "competence" to "performance” (Corpas Pastor, 2008: 28).

With regard to translated language, this type of language has not always been well accepted by all authors: "Translations, however good and near-perfect they may be (but rarely are), cannot but give a distorted picture of the language they represent. Linguists should never rely on translations when they are describing the language. That is why translations have no place in reference corpora” (Teubert, 1996: 250). According to Teubert, translated texts are defined as a distorted picture of the language and therefore they can not constitute a reliable source for contrastive analysis. 
In relation to the translated text, we believe that there are some intrinsic characteristics of the translated language which make it different from the source or original language. In general, the translation techniques enable us to study how translation equivalence works in relation to the original texts. Nevertheless, there has been some disagreement amongst scholars about the definition of this notion. There is even a lack of consensus concerning the terminology used for the categories. Moreover, different classifications have been provided and the terms used often overlap (Molina and Hurtado Albir, 2002: 499).

In this regard, we believe that corpus translation studies should not be limited to the establishment of equivalence relations between the source and the target language but they should also provide the actual steps taken by the translator in the translation process of each micro-unit, that is to say, they should also provide translation techniques.

Many of the limitations exposed above can be counteracted by adopting a cognitive analysis of the English gerund. This analysis must be considered the base for the contrastive analysis between the English gerund and its Spanish counterparts from a cognitive point of view (section 3). After this, we will provide a translation study (section 4) which provides a perspective that is complementary to the contrastive analysis.

\section{METHODOLOGY}

Before providing the contrastive analysis and the translation study (section 3 and 4 respectively), it seems necessary to present the empirical base used for our work. As we have seen in the previous section, some authors still question the value of parallel corpora and translated language. A parallel corpus is a corpus that contains a collection of original texts in language L1 (source language) and their translations into a set of languages L2 (target language). Our corpus is the simplest version, where only two languages are involved: one of the corpora is an exact translation of the other. This type of corpus is very interesting for contrastive analysis. In fact, parallel corpora are relevant in contrastive linguistics for two main reasons (Izquierdo Fernández, 2008: 62): firstly, because "they give new insights into the languages compared -insights that are likely to be unnoticed in monolingual corpora” (Johansson, 1998: 4); and, secondly, because "a parallel corpus can capture relations of sense as well as form, which would be very hard to capture without such data” (Mauranen, 2002: 161).

Furthermore a linguistic corpus not only allows us to iron out difficulties, verify existing theoretical principles and analyse or describe language based on rules and norms but also helps us to propose new lines of research: "Corpus-based discourse analysis should therefore play an important role in terms of removing bias, testing hypothesis, identifying norms and outliers and raising new research questions” (Baker, 2006: 183). 
Concerning the validity of translated texts, we fully agree with Mauranen (2002: 161) when he states that these texts "constitute a valuable source of evidence for contrastive research" as they provide "language that has been used in its normal communicative contexts by a large number of users” (Mauranen, 2002: 161).

Nevertheless one may question the role of the corpus in Linguistics. Our position coincides with Baker (2006: 183) and we consider corpus linguistics to have a complementary nature in the sense that it is not the only possible methodology to follow, but it is essential for the purpose of linguistic analysis: "It should not replace other forms of close human analysis, but act in tandem with them. The corpus is therefore an extremely useful instrument to add to the workbook of techniques available to discourse analysts. But it should not mean that we can throw away all of our existing tools”. And we also agree with Teubert (2005: 1085) to consider corpus linguistics an empirical methodology based on the actual use of language: "Today, the corpus is considered the default resource for almost anyone working in linguistics. No introspection can claim credence without verification through real language data. Corpus research has become a key element of almost all language studies (Teubert, 2005: 1085).

At this point it is important to clarify our position on the traditional dichotomy between corpus-based and corpus-driven. The dichotomy between corpus and intuition respectively tends to disappear in the current scenario (Corpas Pastor, 2008: 54) and the current trend is to use both: "Linguists are increasingly limiting themselves exclusively neither to corpora nor to intuition. They are using both” (McEnery and Gabrielatos, 2006: 46). In this regard, our interest focuses on corpus-based understood as a type of corpus that provides us with data to confirm our research hypothesis.

Before concluding this section, we will present the most relevant features of our corpus. Our corpus is an English-Spanish parallel corpus which includes around 1000 pairs of English original texts and their Spanish translations. The corpus is made up of 12 original texts of six authors and their translations (see Table 1).

The corpus is homogenous in terms of gender and date of publication. All works belong to contemporary narrative fiction and date from 1994 to 2002. The choice of the contemporary narrative fiction genre was made for two reasons: firstly, it provides examples of the current use of language; and, secondly, the genre of fictional narrative has a marked descriptive character with a wide range of narrative possibilities (e.g. descriptions, narratives, monologues, dialogues, etc.) favouring the presence of the English gerund. In fact these narrative possibilities are consistent with the nature of the English gerund as a form with a wide variety of functions (Fente, 1971: 99). 


\begin{tabular}{|c|c|c|c|c|}
\hline Author & Genre & Publication & Original Text & Spanish Translation \\
\hline \multirow[t]{3}{*}{ D. Lodge } & Novel & 2002 & Thinks (2001) & $\begin{array}{l}\text { Pensamientos } \\
\text { secretos(=PENSA) }\end{array}$ \\
\hline & & 2001 & Therapy (1996) & \\
\hline & & & & Terapia (= TERA). \\
\hline \multirow[t]{3}{*}{ D. Lessing } & Novel & 1996 & Love, again (1996) & $\begin{array}{l}\text { De nuevo, el amor }(= \\
\text { AMOR) }\end{array}$ \\
\hline & & 2006 & The sweetest dream (2001) & \\
\hline & & & & $\begin{array}{l}\text { El sueño más dulce (= } \\
\text { SUEDUL) }\end{array}$ \\
\hline \multirow[t]{3}{*}{ N. Gordimer } & Novel & 1995 & None to accompany me (1994) & $\begin{array}{l}\text { Nadie que me acompañe } \\
\text { (= NADIE). }\end{array}$ \\
\hline & & & The pickup (2001) & \\
\hline & & 2005 & & El encuentro (= ENCUEN) \\
\hline \multirow[t]{2}{*}{ J. M. Coetzee } & Novel & 2004 & Youth (2002) & Juventud (= JUVEN). \\
\hline & & 2000 & Disgrace (1999) & Desgracia (= DESG). \\
\hline \multirow[t]{3}{*}{ J. Updike } & Novel & 1998 & In the beauty of the lilies (1996) & $\begin{array}{l}\text { La belleza de los lirios (= } \\
\text { LILIE) }\end{array}$ \\
\hline & & & Licks of love (2000) & \\
\hline & & 2003 & & $\begin{array}{l}\text { Conejo en el recuerdo y } \\
\text { otras historias (= BELI). }\end{array}$ \\
\hline \multirow[t]{2}{*}{ P. Roth } & Novel & 1997 & Sabbath's theater (1995) & $\begin{array}{l}\text { El teatro de Sabbath } \\
\text { (= TEASAB) }\end{array}$ \\
\hline & & 2001 & The human stain (2000) & $\begin{array}{l}\text { La mancha humana } \\
\text { MANHU) }\end{array}$ \\
\hline
\end{tabular}

Table 1. The English-Spanish Corpus’ Texts

As for the translations, the prestige of the selected authors (six authors) as well as the variety of works (two works per author, twelve pieces in total) ensure, on the one hand, that our analysis is not limited to a specific variety or idiolect of English and on the other that there is an interesting range of language options. Moreover, it is important to note that we have chosen translators who translate into their mother tongue, which guarantees that the translations can be considered the typification of current and real language (De Kock, 1986: 40).

\section{CONTRASTIVE ANALYSIS}

Previous to the contrastive analysis itself, we will provide the cognitive characterization of the English gerund (3.1), after which we will focus on the cognitive resemblance of the Spanish counterparts with respect to the English gerund (3.2.). In this last section, the three most frequent Spanish counterparts (i.e. the infinitive, the substantive and the that-clause) will be studied (see Table 2). 


\begin{tabular}{|c|c|c|}
\hline Counterparts & Absolute Frequency & Relative Frequency \\
\hline Infinitive & 236 & $50 \%$ \\
\hline Substantive & 80 & $17 \%$ \\
\hline That-clause & 43 & $9 \%$ \\
\hline Main verb & 40 & $9 \%$ \\
\hline Gerund & 29 & $6 \%$ \\
\hline Relative clause & 22 & $5 \%$ \\
\hline Zero & 11 & $2 \%$ \\
\hline Participle & 7 & $1 \%$ \\
\hline Version proposed by the Translator & 7 & $1 \%$ \\
\hline Total & 474 & $100 \%$ \\
\hline
\end{tabular}

Table 2. The distribution of the Spanish Counterparts

Our decision to present the infinitive, the substantive and the that-clause is justified by the fact that they represent very different construals from the English gerund and therefore they reflect contrasting perspectives. It is necessary to clarify that the term "counterparts" denotes a graduated scale of equivalence that is directly dependent on the context: "Whether a certain lexical unit in the target language is translationally equivalent to a lexical unit in the source language depends to a great deal on the context, which also consists of lexical units" (Teubert, 1996: 247-248).

Based on the data shown in Table 2, we see that the English gerund corresponds mainly to the Spanish infinitive and the Spanish substantive in terms of frequency, and secondly that the English gerund is not automatically translated into the Spanish gerund. In general, the majority of the most frequent counterparts can be predicted within the Spanish system (i.e. infinitive, substantive, that-clause, gerund, relative clause, etc.). In contrast we observe that the frequency of less predictable translations put the concept of orthonymy into play (i.e. Zero, version proposed by the translator). We consider it necessary to insist that the concept of orthonymy designates the most natural, habitual and authentic way of expressing the source language meaning into the target language (Chevalier and Delport, 1995).

On the whole it can be stated that corpus linguistics provides qualitative information on the role and the use of a particular counterpart in the case of our study, as well as quantitative information on the tendency to use that specific counterpart: "Contrastive linguistics now have a way of testing and quantifying intuition-based contrastive statements in a body of empirical data that is vastly superior -both qualitatively and quantitatively- to the type of contrastive data that had hitherto been available to them (Granger, 2003: 18).

\subsection{The contribution of the cognitive approach}

As noted earlier, the traditional characterization of English gerund has been proven to be inadequate. We argue that the cognitive approach makes it possible to establish a valid characterization of the English gerund. In this context, both the progressive -ing form and the nominalization process have shown to be the relevant elements to do so. 
The progressive -ing form does three things to a verb stem: (i) it conceptualizes the event holistically by suspending sequential scanning, therefore the English gerund has summary scanning, which makes the profiled relationship non-processual; (ii) the -ing confines the profiled relationship to an immediate temporal scope consisting of some internal portion of the overall relationship; and (iii) it construes this portion at a level of abstraction that neutralizes its differences (its qualitative uniformity) (Langacker, 2008: 155).

Concerning the nominalization process, it explains the fact that the component states of the English gerund are profiled in a collective way and they are part of an abstract region or a mass-like construal.
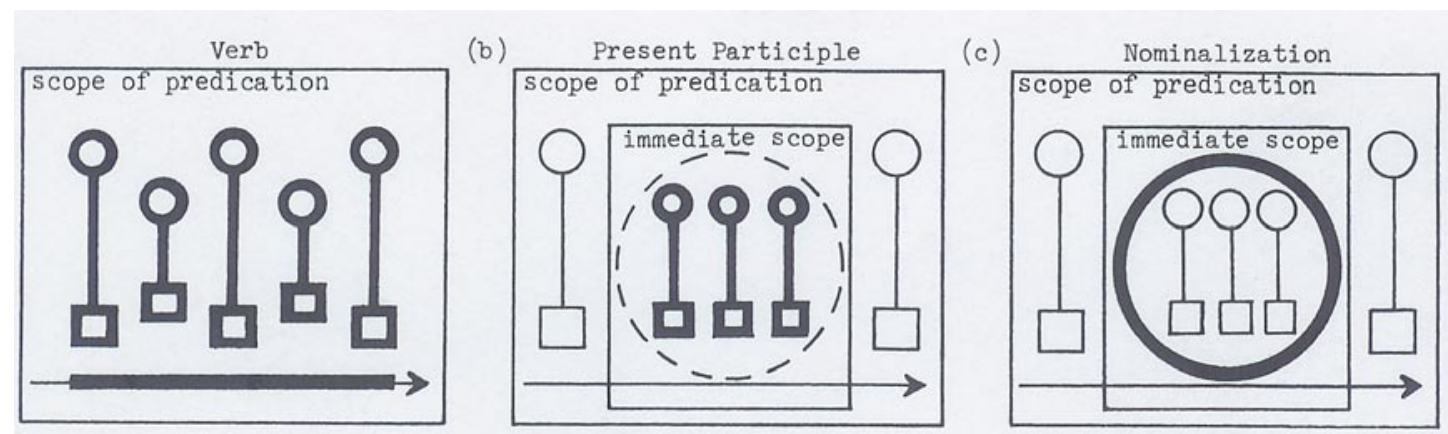

Figure 1. Verb and Nominalization (Langacker, 1991: 24)

The impact of the -ing form is represented in Figure 1. There exists an abstract region intrinsic to every verb: it can be latent as diagrammed in (1b) with a broken line ellipse or it can be completely profiled as depicted in (1c) with a circle, as in the case of the English gerund. In this particular case, the nominalization process justifies this type of profile.

Taking into account all the previous cognitive observations, we argue in this paper that the English gerund is an event seen as a whole from a close perspective of the conceptualizer and it is conceptualized as an abstract entity which implies a nominal profile without a temporal internal structure.

\subsection{Translation options or counterparts}

After this presentation of the cognitive characterization of the English gerund, we will concentrate on the cognitive coincidences and differences between this category (the English gerund) and the three most frequent Spanish counterparts (i.e. infinitive, substantive and thatclause).

The high frequency of the Spanish infinitive counterpart can be justified by its cognitive similarity to the English gerund.

The Spanish infinitive and English gerund have two important points in common. In the first place, the two categories can be interpreted as an event construed as a whole without an internal temporal structure (Albalá, 1988; Hernanz, 1999; Fernández Lagunilla, 1999; 
Verhaert, 2006). According to Declerck (2006) this coincidence can be reformulated in terms of aspect, in particular, the Spanish infinitive and the English gerund coincide in the fact that they have a perfective aspect: “[...], there is PERFECTIVE ASPECT when the verb form used reflects the fact that the speaker wants to refer to the actualization of a situation in its entirety, i.e that he views the situation as if there were a temporally unstructured whole. This means that he does not refer to the situation as having an internal structure (with a beginning, middle and end)" (Declerck, 2006: 99).

In particular, according to Albalá's classification (1988: 14) based on how time is interiorized, the Spanish infinitive represents the neutral member and indicates a process without contemplating the possibility of its ending (1988: 14). This corresponds to the cognitive characterization of the English gerund interpreted as an abstract thing lacking an internal time structure as seen in (3.1.).

Secondly, the Spanish infinitive and the English gerund establish a subordinate relationship with the main verb or predicate. The fact that the Spanish infinitive lacks time, number and person endings entails neutral aspectuality, and as it is unable to establish an agreement relationship with the subject (Hernanz, 1999: 2201), it must be inserted in constructions that provide this agreement relationship. This subordinate relationship with the main verb implies, in turn, a high cohesion level (Hernanz, 1999; Gómez Torrego, 1999, Givón, 1993) as depicted by an arrow:

3a. nadie podría recordar quién había sugerido utilizar la música de Julie (AMOR 994)

3b. no one could remember who had suggested using Julie's music (LOVE 994)

The concept of cohesion is directly related to the proximity principle (Givón, 1993). This principle (Givón, 1993: 23) implies that the greater the degree of conceptual cohesion between the complements and the main verb, the greater the degree of syntactic and semantic cohesion between them. In terms of Rohdenburg (1995: 368), this syntactic and semantic cohesion has to do with the complexity of a particular complement clause. According to this author the degree of complexity of a complement clause is shown by the number of complements and adjuncts there are between the complement and main verb or predicate. A high level of cohesion between the Spanish infinitive and the English gerund with the main verb or predicate is reflected by the fact that there are no complements or adjuncts between them; in other words, there is no linear distance between them.

At the same time, in some contexts, the Spanish infinitive and English gerund can appear with their subject. In these cases they differ in the role their subjects play in these constructions. In Spanish the agentive role of the infinitive's subject has a higher predominance than in English (Hanegreefs, 2008: 93) as discussed in the paragraphs that follow. 
In the case of the Spanish infinitive in (4), its subject (le) is more noticeable as far as agentivity and topicality are concerned (Delbecque and Lamiroy, 1999). The subject's preposing position in relation to the main verb and the infinitive is conditioned by "its degree" of agentivity and topicality (Delbecque, 1987; 2005). With regard to the agentivity nature we could argue that the closer the subject is to a prototypical agent, the less likely it may appear postponed (Hanegreefs, 2008: 87). On the other hand, this "subject's preposing position" shows that this particular agentive entity has the capacity to trigger the event and is to be considered the focus in terms of topicality (Langacker, 1991: 443; Soares da Silva, 2003). Indeed in (4a) the infinititve's subject (le) is a prototypical experiencer and its preposing with regard to "he visto" and "producir" highlights "its" prominence as a topic of discourse.

4a. Le he visto producir en serie las comidas, asar a la parrilla todos esos kebabs, la camiseta empapada en sudor, reluciente de grasa. (TEASAB 89)

4b. I've seen him churning out the dinners, grilling those kebabs in his sopping T-shirt. (SAB 89)

Regarding the second most frequent Spanish counterpart, the substantive, this counterpart and the English gerund coincide in three important points: (i) the two categories express a holistic interpretation; (ii) both are discontinuous and unbounded; and (iii) the abstract region profiled by both of them can be explained in terms of their qualitative homogeneity: the profiled relationship is construed as homogenous (Langacker, 1990: 99; 2008: 155).

Concerning the concept of "unboundedness", this implies that the substantive and the English gerund express a profiled region lacking inherent bounding within the scope of predication, since the endpoints of the process fall outside the relevant predication (see Figure 2).

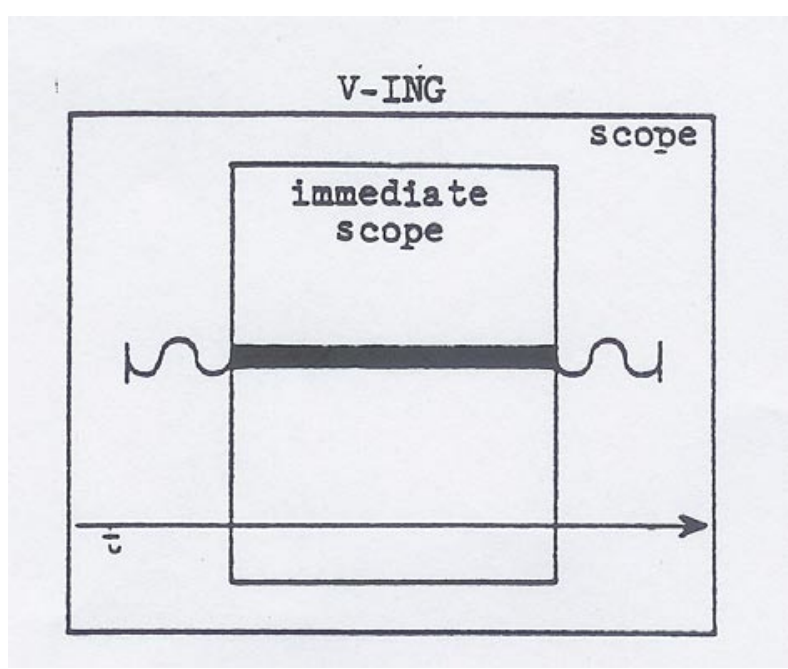

Figure 2. No inherent bounding (Langacker, 2008) 
As regards the profile of these categories, they can be considered an abstract substance due to their qualitative uniformity (Langacker, 1990: 99; 1991: 27; 2008: 155) as shown in Figure 3.

Mass Noun

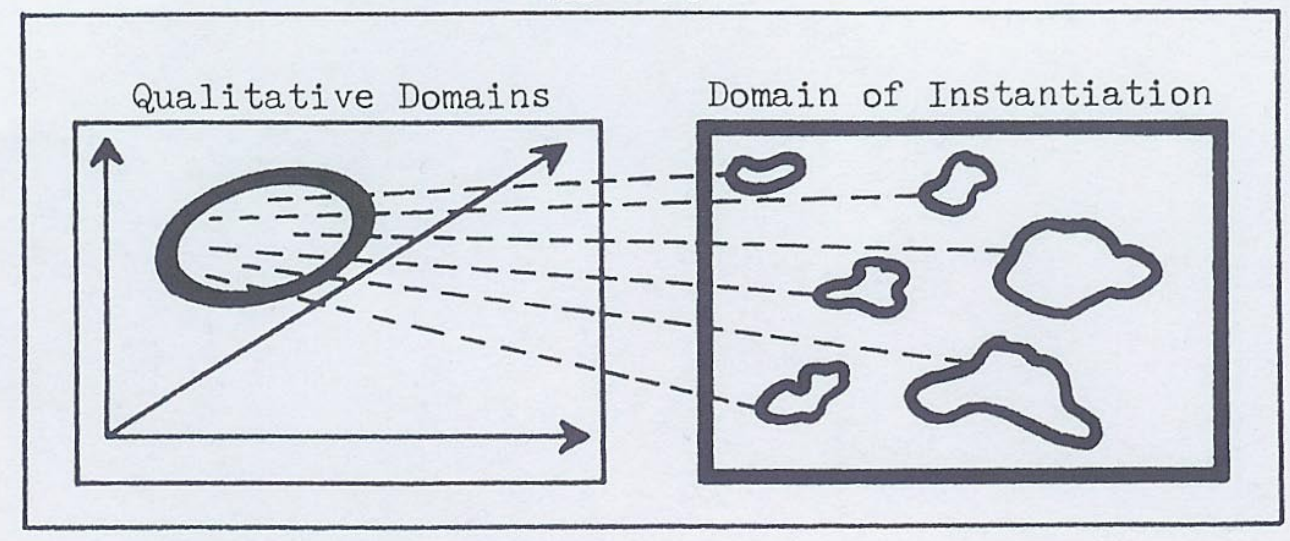

Figure 3. Qualitative uniformity

Before examining the differences between the Spanish substantive and the English gerund, it seems necessary to reflect on the nature of substantives found in the database. In order to distinguish the different degrees of abstraction in the nominal entity, we have adopted Delbecque and Lamiroy's scheme (1999: 1968). According to these authors, the different nominal entities (i.e. objects, events, propositions and metalinguistic objects) are characterized as follows: the concrete nouns or substantives (e. g. boy, dog, house) designate discrete physical objects and are, under normal conditions, relatively constant in their perceptible properties: they are basic entities. Events exist in the physical world, but they are less concrete than physical objects, although they can still be localized in space and time. When there is no spatio-temporal location and it is impossible to designate a nominal entity deictically, nominal entities become purely intensional objects that we refer to as propositions. And finally, metalinguistic objects correspond to speech acts.

In this context, we can corroborate that the Spanish substantive and the English gerund differ in one important aspect: their degree of abstraction. The Spanish substantive displays different conceptualization levels as it can evoke an object (e.g. chorro de agua, chapoteo, pan, etc.), an event (e.g. situación, sensación, goce, convivencia, separación, asistencia, etc.), a proposition (e.g. encanto, concepto, normalidad etc.) and a metalinguistic object (e.g. bromas, monsergas, consejos, fraseo etc.) according to Delbecque and Lamiroy's scheme (1999). Nevertheless it is important to note that more than half of the substantives evoke an event and this justifies its being the second most frequent counterpart.

In order to complete this section, we will focus on the that-clause. This counterpart provides a contrasting perspective in relation to the previous Spanish counterparts (i.e. the infinitive and substantive). The conceptualization of the that-clause is different to that of the 
English gerund in three aspects: firstly, the that-clause shows a sequential scanning or, to put it another way, the component states are construed individually. Secondly, the that-clause has its own grounding (Langacker, 2008: 354). And finally, it shows independent clause behaviour.

According to Hanegreefs (2008: 121), such “independent behaviour” can be understood from two facts: firstly, the presence of the complementizer "that" marks the transition between the that-clause and the rest of the construction. And secondly, the that-clause lacks an NP which operates as a "pivot" between the two constituents and thus creates a greater conceptual distance between them.

Due to its independent clause behaviour, the that-clause construction evokes two different scenarios, symbolized by two different boxes, with its own participants:

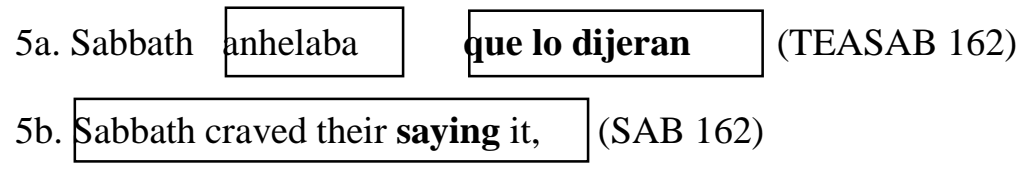

As previously shown, the that-clause establishes a syntactically and semantically independent relationship with the rest of the construction, whereas the English gerund (their saying) maintains a syntactically and semantically dependent relationship with the main verb (craved) in (5b); this circumstance is depicted by a single box.

On the whole, the cognitive analysis is the right approach for two reasons. Firstly, the cognitive analysis establishes a coherent characterization of the English gerund. Secondly, this analysis explains the equivalence between the English gerund and its Spanish counterparts in terms of their cognitive resemblance. Moreover, the greater the cognitive similarity between the previous categories (i.e. the English gerund and its Spanish counterparts), the higher the frequency of each counterpart (i.e. the infinitive, substantive and the that-clause are the first, second and third most frequent counterparts respectively).

\section{TRANSLATION STUDIES}

So far we have presented the contrastive analysis and we will now focus on the translation study. Using our corpus, we will present, on the one hand, the contexts and the most relevant factors which help to explain the presence of these particular counterparts. The contexts and factors can generally be explained by the cognitive resemblance between the English gerund and its Spanish counterparts. We will, on the other hand, provide the particular translation techniques observed in the Spanish counterparts included in this paper

Before proceeding to the translation study itself, it seems necessary to make some observations. Our work is confined to the English gerund functioning as direct object and 
prepositional complement. These functions and constructions are the reference point for the analysis of the Spanish counterpart. The inclusion of this information aims to illustrate the distribution of the counterparts depending on the function of the English gerund. However, from the data, it is evident that the English constructions alone do not explain the presence of counterparts and therefore we must consider other factors that help to justify their presence.

\subsection{Contexts and factors that justify translation options or counterparts}

In relation to the Spanish infinitive, there exist two contexts which help to understand its translation. The first context can be predicted from the Spanish system: the English sequence [V + English gerund] is translated into a [V + Spanish infinitive] and a [Verbal Periphrasis with infinitive] in Spanish. The second context reflects the following English sequence [Prepositional phrase + English gerund] that corresponds to [Prepositional phrase + Spanish infinitive], as shown in Table 3.

\begin{tabular}{l|lc}
\hline \multicolumn{1}{c|}{ English gerund constructions } & \multicolumn{1}{c}{ Spanish infinitive constructions } & Total \\
\hline $\begin{array}{l}\text { English gerund as direct object } \\
\text { [V ] + English gerund }\end{array}$ & [V + Spanish infinitive $]$ & 99 \\
& & \\
\hline $\begin{array}{l}\text { Prepositional English gerund } \\
\text { [Prepositional phrase] + English gerund }\end{array}$ & [Prepositional phrase + Spanish infinitive $]$ & 137 \\
\hline
\end{tabular}

Table 3. The distribution of the Spanish infinitive depending on the function of the English gerund

Regarding the first context, the infinitive is the assumed or established grammatical category in Spanish, according to Hernanz (1999: 2277), when it appears with a main verb (V) that belongs to certain semantic classes (i.e. cause, cognitive perception, communication, emotion and physical perception and verbs):

6a. [...] she hated feeling shut in, (LOVE 977)

6b. [...] ella odiaba sentirse encerrada, (AMOR 977)

According to Hernanz (1999: 2277) the use of the infinitive with the semantic classes cited above can be explained by two factors. Firstly, from a semantic point of view these verbs have as a common denominator the fact that they refer to mental activities, judgments, feelings, desires, fears, etc... And as for the NP controller, this NP is the only candidate to act as the subject of the main verb (V). Besides, as noted earlier, the infinitive shows no linear distance with the main verb and this reveals the close "conceptual" distance between them (Achard, 1998: 85; Hanegreefs, 2008: 56). This circumstance is closely linked to the concept of subordinate relationship as detailed in subsection 3.2.

As discussed in the first paragraph of this section, there is a group of English constructions [V + English gerund] that corresponds to the sequence [Verbal Periphrasis with infinitive] in Spanish. From the database, it is important to note that these verbs (V) are 
limited to the semantic class of intention, success or failure and aspectual verbs. Due to space limitations we will focus on the aspectual verbs as seen in:

7a. [...] before he began doing penance for his defeat by becoming a carpenter (HUM 63)

7b. [...] antes de que empezara a hacer penitencia por su derrota convirtiéndose en carpintero. (MANHU 63)

According to Gomez Torrego (1999: 3345), the Verbal Periphrasis is the union of two or more verbs that constitutes a single verbal unit. These verbal units are characterized by not having a complementary or subordinate relationship (Gómez Torrego, 1999: 3325) between the different elements (empezara a hacer) in contrast to the English construction (began doing). In addition, the Spanish system proves to be defective, because an infinitive is always needed after a preposition ( $a+$ hacer). However it is important to note that the notion of Verbal Periphrasis is a point of disagreement between different authors (Gómez Torrego, 1999; Luna Traill, 1980). In fact, we believe that Verbal Periphrasis has a "gradual nature" (Gómez Torrego, 1999: 3335) that would explain such discrepancy.

From the data analysed we can conclude that when the infinitive is part of a verbal periphrasis, it shows a different profile compared to the English gerund. Indeed, the infinitive does not establish any relationship with the main verb, as both elements form a single verbal unit and neither of them has a complementary relationship "over each other", while the English gerund expresses a subordinate relationship with the main verb.

The second context that explains the presence of the Spanish infinitive reflects the sequence [Prepositional phrase + English gerund] that corresponds to [Prepositional phrase + Spanish infinitive]:

8a. It was Sabbath who, [...], had assisted her in becoming estranged from her orderly life and in discovering the indecency to supplement the deficiencies of her regular diet. (SAB 105)

8b. Fue Sabbath quien, [...], la ayudó a apartarse de su vida ordenada y a descubrir la indecencia para complementar las carencias de su dieta regular. (TEASAB 105)

In these cases, the Spanish system proves to be defective compared to the English system, as in Spanish the presence of an infinitive after a preposition is always mandatory and we cannot use a gerund instead (*la ayudó a apartándose).

In general we can say that the presence of the Spanish substantive cannot be explained in terms of the presence of a main verb or a prepositional predicate in the English construction. There are other factors of a different nature which must be taken into account as described in the paragraphs below and shown in Table 4.

Spanish tends to use the substantive in three contexts. The first context is related to the nature of the English gerund. The English gerund has both nominal and verbal uses and this characteristic explains its ambivalent nature: "The gerund is a substantival form of the verb 
which is intermediate between the infinitive and the noun of action; i.e. it is of a less distinctly verbal nature than the infinitive; and of a more distinctly verbal nature than the noun of action” (Poutsma, 1923: 101).

\begin{tabular}{l|lc}
\hline \multicolumn{1}{c|}{ English gerund constructions } & \multicolumn{1}{|c}{ Spanish substantive } & Total \\
\hline $\begin{array}{l}\text { English gerund as direct object } \\
{[\mathrm{V}]+\text { English gerund }}\end{array}$ & {$[\mathrm{V}+$ Spanish substantive $]$} & 38 \\
\hline $\begin{array}{l}\text { Prepositional English gerund } \\
\text { [Prepositional phrase] + English gerund }\end{array}$ & $\begin{array}{l}\text { [Prepositional phrase + Spanish } \\
\text { substantive }]\end{array}$ & \\
\end{tabular}

Table 4. The distribution of the Spanish substantive depending on the function of the English gerund

Moreover, there are some authors that define the English gerund as a noun belonging to the verb system and having the syntactic characteristics of the inflected forms of the verb: " $\mathrm{A}$ gerund is always a noun. Its first or only word ends with -ing. It belongs to the verb system. Like other verbs the gerund is modified by the usual adverbs, and the gerund of a transitive verb-base can have an object...” (Joos, 1968: 40). When the most nominal English gerund appears in English, Spanish tends to favour the presence of a substantive. In these cases, the English gerund can be preceded by nominal premodifiers (such as the definite article "the", the possessive pronoun, the negation "no" or the indefinite pronoun):

9a. we thought that if we praised your writing it would look like toadying to the teacher. (THIN 738)

9b. que pensamos que si alabábamos su texto sería como darle coba, y que si lo criticábamos sería una grosería. (PENSA 738)

The second context highlights the importance of the nature of the predicate. Based on the data of our corpus, we corroborate that whenever the English predicate preceding the English gerund is a noun phrase (level in 10a). Spanish tends to provide a substantive:

10a. This is a different level of suburban entertaining. (PICK 545)

10b. Éste es un nivel diferente de disfrute de barrio residencial. (ENCUEN 545)

Moreover the presence of nominal premodifiers (i.e. suburban) tells us that the English gerund in these contexts should be interpreted as an "instance" which is completely coherent with its translation into the substantive category.

Pragmatics explains the third context. When the English gerund is part of a succession of complementary information expressed with different grammatical categories (“interviewing” and "investigation" being a gerund and substantive respectively), in Spanish a substantive is predominant:

11a. She does her share of interviewing and investigation. (NONE 15)

11b. Participa también en las entrevistas y en la investigación. (NADIE 25) 
We argue that in (11a) the presence of "investigation" determines the presence of the substantive "entrevistas" in (11b). In these cases, the Spanish system manifests a limitation because it is unable to combine two different categories (infinitive and substantive: *Participa también en entrevistar y en la investigación).

In order to provide a complete overview of the Spanish counterparts, we will focus on the Spanish that-clause. As in the case of the substantive, the presence of a main verb or a prepositional phrase in English does not explain on it is own the presence of the that-clause, so we must take into account other elements, as explained in the paragraphs below and shown in Table 5.

\begin{tabular}{l|lc}
\hline \multicolumn{1}{c|}{ English gerund constructions } & \multicolumn{1}{c}{ Spanish that-clause } & Total \\
\hline $\begin{array}{l}\text { English gerund as direct object } \\
\text { [V ] + English gerund }\end{array}$ & {$[\mathrm{V}+$ That-clause $]$} & 21 \\
\hline $\begin{array}{l}\text { Prepositional English gerund } \\
\text { [Prepositional phrase }+ \text { English } \\
\text { gerund }\end{array}$ & [Prepositional phrase + That-clause $]$ & 22 \\
\hline
\end{tabular}

Table 5. The distribution of the Spanish that-clause depending on the function of the English gerund

Three contexts explain the presence of the Spanish that-clause. The first two can be predicted from the Spanish system. Firstly, when the subject of the English gerund is present or explicit in the construction, Spanish tends to "rescue" the subject of the English gerund as the subject of the that-clause (i.e. you/tú):

12a. Since when? Drenka, I see you suffering, I don't want you to suffer. (SAB 148) 12b. ¿Desde cuándo? Veo que (tú) estás sufriendo, Drenka. (TEASAB 148)

In these cases, the English gerund proposes a single scenario with a single participant responsible ("I"). In contrast to this, the that-clause opens a new scene and proposes the notional subject of the English gerund ("you") as an active participant with its own responsibility and autonomy (i.e. “que (tú) estás sufriendo”).

Secondly, when the English gerund takes a passive form, Spanish shows a tendency to privilege active constructions instead of passive constructions, which explains why Spanish favours the presence of the that-clause:

13a. She doesn't like being crowded in her own kitchen. She has never been very clever at household tasks, it used to make Harry sarcastic. (RAB 273)

13b. No le gusta que nadie le acompañe a la cocina. Nunca ha sido mañosa para las tareas domésticas, y Harry solía recordárselo con sarcasmo. (CONEJ 273)

The use of the passive in English denotes the presence of another agentive entity that can be inferred from the context or can refer to an unspecified/general agentive entity. However, in Spanish this results in a new participant responsible for the event denoted by the that-clause (i.e. "que nadie le acompañe a la cocina”). 
Lastly, we confirm that the third context cannot be predicted from the target language system. According to the RAE (1931: 447) when the complement and main clause have the same subject in common, Spanish favours the presence of an infinitive. The use of a thatclause in those cases seems to be inadequate in Spanish. In our view, it is a translator's choice aimed to provide two windows or two different scenarios for each of the two activities carried out by the same agent in order to stress their different conceptual nature (i.e. "imagina" and “enseña”):

14a. he imagines showing her over the mysteries of the bindery and cataloguing room (YOU 420)

14b. Se imagina que le enseña los misterios del taller de encuadernación y de la sala de catalogación (JUVEN 420)

\subsection{Translation techniques}

In this section, we will discuss the translation techniques observed in the translation product that we have analyzed in this paper. As a basis of our analysis, we have adopted the translation technique classification proposed by Molina and Hurtado Albir (2002). In general, this classification seems to provide an adequate and well-founded proposal but, from the data observed, we must include a new translation technique (i.e. the expansion technique), as defined by Izquierdo (2008: 310). We believe that the translation techniques establish a symbiotic relationship with the translational options or counterparts. On the one hand, a particular technique gives rise to a particular option and, on the other hand, a particular option or counterpart exemplifies or explains a particular technique (Izquierdo, 2008: 393).

According to Molina and Hurtado Albir (2002: 499), the category of translation techniques allows us "to describe the actual steps taken by the translator in each textual micro-unit and obtain clear data about the general methodological option chosen”. Nevertheless, we believe that this category should be distinguished from the concepts of translation method and translation strategy as explained by Molina and Hurtado Albir (2002: 507-508). Translation method refers to the way a particular translation method is carried out, that is to say, the global option chosen by the translator that affects the whole text. This is opposed to translation techniques, which affect the way micro-units of the text are translated (Molina and Hurtado Albir, 2002: 508). No matter what method or technique is chosen in the translation process, there may be problems to be solved. The translation strategies are the procedure triggered by the translator to solve problems that emerge during the translation process, whereas the translation techniques affect the result, or in other words, the translation techniques offer the solution for a particular translation unit (Molina and Hurtado Albir, 2002: 508).

There are some characteristics of these techniques that are relevant to our study. Firstly, these techniques affect the way micro-units of the text are translated. Secondly, they have a 
discursive and contextual nature. And finally, these techniques are classified according to comparison with the original (Molina and Hurtado Albir, 2002: 509).

The Spanish infinitive exemplifies the translation technique of established equivalence (Molina and Hurtado Albir, 2002: 510). This technique implies the use of a term or expression recognized (by dictionaries or language in use) as an equivalent in the target language. The infinitive that materializes this technique represents $50 \%$ in our sample. The cognitive resemblance of the Spanish infinitive with the English gerund may account for its central position in actualizing this technique: the English gerund and the Spanish infinitive share an interpretation as an abstract region and they both establish a subordinate relationship with the main verb, as explained in detail in subsection 3.2.

Even though there is agreement about the status of the Spanish infinitive as the established equivalent of the English gerund in contrastive and translation studies, we think that most of these studies have not addressed the issue satisfactorily.

Although the subject of the English gerund and its Spanish counterparts has been studied from several perspectives, there are few relevant studies so far. There exist studies (Álvarez, 1991; Fente, 1971; Criado de Val, 1972; Losada, 1980; Querada, 1972) that coincide in considering the -ing a unique form with two functional variants, the gerund and participle categories that must be analyzed separately. However, we detect a common problem to all these studies: they lack an exhaustive linguistic analysis. For example, most of these studies only provide a list of equivalents with their respective examples. Consequently, the infinitive does not receive an appropriate linguistic description and its position as an established equivalent does not get the attention it deserves.

There are more recent studies than those cited in the preceding paragraph. In particular, we highlight the studies of Piñeiro and Garcia (2001), Alonso García (2003) and Izquierdo (2006 and 2008). Their research shares a functional descriptive approach. These studies provide, in general, a rigorous linguistic description, but some of them, in particular the work of Izquierdo (2006 and 2008), approach the analysis of the -ing form in a comprehensive manner: all the -ing forms belong to a single category and therefore there is no need to make a distinction between the terms "gerund" and "participle" (Huddleston and Pullum, 2002: 1222). We think that this type of analysis, on the one hand, does not favour the study of the most nominal uses of the -ing as it should and, on the other hand, the low statistical representation of the English gerund, in the sample of these studies, contrasts with its current use and the information obtained from our corpus.

The Spanish substantive illustrates the technique of transposition. The substantive that actualizes this technique reflects $17 \%$ of our sample. The transposition technique is a technique whereby the source text is translated by a resource belonging to a different grammatical category (Molina and Hurtado Albir, 2002: 511): from a non-finite verb, the English gerund, to a substantive, in this particular case. The ambivalent nature of the English 
gerund explains why the transposition technique takes shape by means of the Spanish substantive.

Therefore, due to its nominal and verbal nature (as explained in section 4.1.) it is not surprising that the most nominal uses of the English gerund are materialized by means of the Spanish substantive. In this sense, the corpus helps us spot the contextual elements that explain the presence of the substantive. We have corroborated that, in this case, the English gerund is always preceded by nominal premodifiers or by a noun phrase followed by the preposition of $(\mathrm{NP}+\mathrm{of})$.

In this regard, the Spanish Substantive distances itself from the nominal use of the English gerund and approaches the so-called deverbal nouns in -ing according to Declerck, (1991: 494), which are nouns derived from verbs ending in -ing that generally have a material sense and therefore have ceased to denote the action or state of the verb from which it derives.

The Spanish that-clause actualizes the translation technique of expansion. This technique is not present in the study of Molina and Hurtado Albir (2002) and we have adopted it from Izquierdo's work (2008: 310). The expansion technique is a technique whereby the source text is expanded syntactically into a microtextual unit having a higher rank in the grammatical distribution of the language (Izquierdo, 2008), for example, from a non-finite verb (the English gerund) to a that-clause. The that-clause which materializes this technique represents 9\% of the sample. That-clause's own grounding and its "independent clause behaviour”, as detailed in 3.2., explains why this linguistic resource exemplifies this particular technique.

When the English gerund is preceded by its own subject, the general claim is that the English gerund should be translated by a that-clause (Plann, 1984). This statement could explain the presence of the Spanish that-clause in the first and second contexts described in subsection 4.3. In these contexts, the English gerund's subject is either present or inferred from the context respectively. Therefore, we could argue that in these cases the that-clause also illustrates the established equivalence technique. The third context provided in subsection 4.3. exclusively exemplifies the expansion technique as defined in the previous paragraph. In this context, the English gerund without a subject is translated into a thatclause, in order to emphasize that the same agent, shared by the main and the complement clauses, carries out two activities of different conceptual natures.

In general, there is some coherence between the Spanish translational options or counterparts and the translation techniques. One half of corpus represents the established equivalence technique by means of the Spanish infinitive. The Spanish substantive that exemplifies the transposition technique is a suitable equivalent of the English gerund due to its nominal nature. Also, the Spanish that-clause with a nominal dimension actualizes the expansion technique due to its independent clause behaviour. 


\section{CONCLUDING REMARKS}

Based on the data extracted from our corpus, we have been able to examine the relationship between the English gerund and its Spanish counterparts from two complementary perspectives: a contrastive study from a cognitive point of view and a descriptive translation study.

Firstly, the contrastive study explains the equivalence between the English gerund and its Spanish counterparts from a cognitive approach. We have corroborated that the characterization of the English gerund from its nominal profile constitutes the base for the analysis between this category and the most frequent counterparts, as they all have the interpretation of an abstract region in common. Secondly, the translation study has, on the one hand, described the most relevant contexts and factors that explain the presence of the Spanish counterparts and detected, on the other, the translation techniques observed in the translation product analyzed in this paper. And finally, parallel corpora and translated texts have shown to be adequate resources for both our contrastive and our translation study.

\section{NOTE}

1. This particular approach has also been adopted in our article entitled "A corpus-based contrastive study between the English gerund and its Spanish counterparts" published in CILC2011 proceedings.

\section{REFERENCES}

Achard, M. (1998). Representation of Cognitive Structures: Syntax and Semantics of French Sentential Complements. Berlin/New York: Mouton de Gruyer.

Albalá, M. J. (1988). Contribución al estudio del gerundio en la lengua español hablada de Madrid. Unpublished Doctoral Dissertation, University of Madrid, Spain.

Alonso García, N. (2003). Descripción de los errores detectados en la interpretación de los equivalentes españoles de la forma inglesa -ing. RESLA 16, 7-21.

Álvarez Calleja, M. A. (1991). Estudios de traducción (inglés-español). Cuadernos de la UNED. Madrid: Mateu Cromo Artes Gráficas.

Baker, M. (2006). Using Corpora in Discourse Analysis. London and New York: Continuum.

Chevalier, J-C \& Delport, M. F. (1995). Problèmes linguistiques de la traduction: l'horlogerie de Saint-Jérôme. Paris: Harmattan.

Coetzee, J.M. (2000). Disgrace. London: Vintage.

Coetzee, J.M. (2004). Youth. London: Secker and Warburg.

Corpas Pastor, G. (2008). Investigar con corpus en traducción: los retos de un nuevo paradigma. Frankfurt am Main: Peter Lang.

Criado De Val, M. (1972). Fisionomía del Español y de las Lenguas modernas. Madrid: Editorial S.A.E.T.A

De Kock, J. \& Verdonk, R. \& Hernanz Molina, C. (1986). Gramática española: enseñanza e investigación. Leuven: Acco.

Declerck, R. (1982). The triple origin of Participial Perception Verb Complements. Linguistic Analysis, 10(1), 1-26.

Declerck, R. (1991). A comprehensive descriptive grammar of English. Tokyo: Kaitakusha

(C) Servicio de Publicaciones. Universidad de Murcia. All rights reserved. IJES, vol. 12 (2), 2012, pp. 111-132 Print ISSN: 1578-7044; Online ISSN: 1989-6131 
Declerck, R. (2006): The Grammar of the English Verb Phrase (Vol. 1). Berlin/New York: Mouton de Gruyter.

Delbecque, N. (1987). Problèmes et méthodes de l'étude de la variation syntaxique: le cas de la position du sujet en espagnol. Leuven: Universitaire Pers.

Delbecque, N. \& Lamiroy, B. (1999). La subordinación sustantiva: las subordinadas enunciativas en los complementos verbales. In I. Bosque \& V. Demonte (Eds.), Gramática descriptiva de la lengua española (Vol. II) (pp.1931-1965). Madrid: Espasa Calpe.

Duffley P. J. (2006). The English gerund-participle, a comparison with the infinitive. Berkeley Insights in Linguistics and Semiotics (Vol. 61). New York: Peter Lang.

Fente Hernanz, R. 1971. Estilística del verbo en inglés y en español. Madrid: Sociedad General Española de Librería.

Fernández Lagunilla, (1999): Las Construcciones de Gerundio. In I. Bosque \& V. Demonte (Eds.), Gramática descriptiva de la lengua española (Vol. III) (pp. 3391-3443). Madrid: Espasa Calpe.

Givón, T. (1993). English Grammar. A function-based introduction (Vol. 2). Amsterdam/Philadelphia: John Benjamins.

Gordimer, N. (1995). None to accompany me. London: Penguin books.

Gordimer, N. (2005). The pickup. London: Bloomsbury.

Gómez Torrego, L. (1999). Los verbos auxiliares. Las perífrasis verbales del infinitivo. In I. Bosque \& V. Demonte (Eds.), Gramática descriptiva de la lengua española (Vol. II) (pp. .3323-3390). Madrid: Espasa Calpe.

Granger, S. (2003). The Corpus Approach: a Common Way Forward for Contrastive Analysis and Translation Studies. In S. Granger, J. Lerot \& S. Petch-Tyson (Eds.), Corpus-based Approaches to Contrastive Linguistics and Translation Studies (pp. 17-29). Amsterdam/New York: Rodopi.

Hanegreefs, H. (2008): Los verbos de percepción visual. Un análisis de corpus en un marco cognitivo. Unpublished Doctoral Dissertation, Katholieke Universiteit Leuven, Belgium.

Hernanz, L. (1999). El infinitivo. In I. Bosque \& V. Demonte (Eds.), Gramática descriptiva de la lengua española (Vol. II) (pp. 2196-2356). Madrid: Espasa Calpe.

Huddleston, R. D. \& Pullum G. K. (2002). The Cambridge Grammar of the English Language. Cambridge: Cambridge University Press.

Ihms, H. (1981). Das 'Half-Gerund'. Ein Irrweg sprachlicher Deutung. Die Neueren Sprachen, 80, 202-207.

Izquierdo, M. (2006). Análisis contrastivo y traducción al español de la forma -ing verbal ingles. León: Universidad de León.

Izquierdo, M. (2008). Estudio contrastivo y de traducción de las construcciones de -ing inglesas y sus equivalentes en español. Unpublished Doctoral Dissertation, University of León, Spain.

Johansson. (1998). On the role of corpora in cross-linguistics research: In S. Johansson \& S. Oksefjell (Eds.), Corpora and Cross Linguistics Research (pp. 3-24). Amsterdam: Rodopi.

Joos, M. (1968). The English verb: form and meanings. Madison (Wis.): University of Wisconsin Press.

Kortmann, B. (1995). Adverbial participial clauses in English. In M. Haspelmath \& E. König (Eds.), Converbs in cross-linguistic perspective. Structure and meaning of adverbial verb forms adverbial participles, gerund. Berlin: Mouton de Gruyter.

Langacker, R. W. (1990). Concept, image and symbol: the cognitive basis of grammar. Berlin/New York: Mouton de Gruyter.

Langacker, R. W. (1991). Foundations of Cognitive Grammar (Vol. 2). Standford: Standford University Press.

Langacker, R. W. (2008): Cognitive grammar: a basic introduction. Oxford: Oxford University Press.

Lessing, D. (1996). Love, again. London: Flamingo.

Lessing, D. (2006). The Sweetest Dream. London: Flamingo.

Lodge, D. (2002). Thinks. London: Secker and Warburg.

Lodge, D. (2001). Therapy. London: Penguin books

Losada Durán, J. R. (1980). La sustantivación en español y en inglés. Senara, 53, 11- 23.

Luna Traill, E. (1980). Sintaxis de los verboides en el habla culta de la ciudad de México. México: Universidad Nacional Autónoma de México. 
Mauranen, A. (2002). Will 'translationese’ ruin a contrastive study? Languages in contrast, 2(2), 161185. Amsterdam/Philadelphia: John Benjamins.

McEnery, T. \& Gabrielatos, C. (2006). English Corpus Linguistcs. In B. Aarts \& A. McMahon (Eds.), The Handbook of English Linguistics (pp. 33-71). Malden, Massachussetts and Oxford: Blackwell.

Molina, L. \& Hurtado, A. (2002). Translation Techniques Revisited: A Dynamic and Functionalist Approach. Meta, XLVII(2), 498-512.

Piñeiro, G. \& García, J. M. (2001). Usos del gerundio: una herramienta para la revisión del texto traducido. In I. Febles (Ed.), La traducción: estrategias profesionales (pp. 87-100). Las Palmas de Gran Canaria: Universidad.

Plann, S. (1984). To translate the English gerund into Spanish, don't use the infinitive. Hispania, 67, 232-239.

Pullum, G. K. (1991). English nominal gerund phrases as noun phrase with verb-phrase heads. Linguistics, 29, 763-799.

Querada Rodríguez-Navarro, L. (1972). Estudio contrastivo del infinitivo inglés y español. Filología Moderna, 45, 299-326.

Quirk, R. \& Greenbaum, S. (1985). A Comprehensive Grammar of the English Language. London: Longman.

Real Academia Española. (2001). Gramática de la lengua española. Madrid: Espasa Calpe.

Rohdenburg, G. (1995). On the replacement of finite complement clauses by infinitives in English. English studies, 76, 367-388.

Roth, P. (1997). Sabbath's Theater. London: Vintage.

Roth, P. (2001). The Human Stain. London: Cape.

Soares da Silva, A. (2003). Da semântica da construção à semántica do verbo e vice versa. In I. Castro \& I. Duarte (Eds.), Razões e emoção. Miscelânea de estudos em homenagem a Maria Helena Mira Mateus (pp. 383-401). Lisboa: Imprensa Nacional Casa da Moeda.

Teubert, W. (1996). Comparable or Parallel Corpora? International Journal of Lexicography 9(3), 238-264.

Teubert, W. (2004). Language and Corpus Linguistics. In M. A. K. Halliday, W. Teubert, C. Yallop \& A. Cermáková (Eds.), Lexicology and Corpus Linguistics (pp. 73-112). United States: Continuum Intl Pub Group.

Teubert, W. (2005). My Version of Corpus Linguistics. International Journal of Corpus Linguistcs, 10(1), 1-13.

Updike, J. (1998). In the beauty of the lilies. London: Penguin books.

Updike, J. (2003). Licks of love. New York, NY: Knopf.

Verhaert, A. (2006). El gerundio no perifrástico del español y sus equivalentes en neerlandés: una aproximación cognoscitivo-funcional. Unpublished Doctoral Dissertation, Katholieke Universiteit Leuven, Belgium. 